\title{
The origins of anti-capitalism in the young Marx
}

\author{
As origens do anticapitalismo no jovem Marx
}

RICARDO LUIS CHAVES FEIJÓ*

RESUMO: Objetiva-se demonstrar, com base em novas biografias, que o ensaio Sobre a questão judaica revela um elemento de antissemitismo que teve um papel fundamental na conversão de Marx ao comunismo. A crítica ao judeu serviu para embasar a tese marxiana de que o capitalismo, identificado com judaísmo, é mau. Novas fontes têm reforçado a suspeita de que não apenas tem-se, neste momento de 1843-44, um elemento de antissemitismo nos escritos de Marx, mas de que esse sentimento ocupou um papel essencial na conversão dele ao comunismo. É isso o que este ensaio procura provar.

PALAVRAS-CHAVE: Marx; antissemitismo; comunismo; sociedade civil; Estado.

ABSTRACT: The objective is to demonstrate, based on new biographies, that the essay On the Jewish Question reveals an element of anti-Semitism that played a fundamental role in the conversion of Marx to Communism. Criticism of the Jew served to support the Marxian thesis that capitalism, identified with Judaism, is evil. New sources have reinforced the suspicion that not only is there at this time of 1843-44 an element of anti-Semitism in Marx's writings, but that this sentiment played a key role in his conversion to communism. This is what this essay seeks to prove.

KEYWORDS: Marx; anti-Semitism; communism; civil society; State.

JEL Classification: B; B3; B31.

\section{INTRODUCTION}

The research on the life of Marx is still an open field, even considering so many biographies about it, among other reasons because the set of manuscripts, published or not, and letters, notes, etc. of the author, and also of the others that surround him, is not yet available to the specialists. Every year new material ap-

\footnotetext{
* Professor Associado da Faculdade de Economia, Administração e Contabilidade de Ribeirão Preto Universidade de São Paulo - Departamento de Economia, Ribeirão Preto/SP, Brasil. E-mail: riccfeij@ usp.br. https://orcid.org/0000-0002-9683-6851. Submitted: 26/July/2018; Approved: 29/October/2018.
} 
pears. ${ }^{1}$ The purpose of this essay is to demonstrate based on new biographies, associated with new primary sources, ${ }^{2}$ that the essay On the Jewish question reveals an anti-Semitic element that played a key role in converting Marx to communism. The criticism of the Jew served to support the Marxian thesis that capitalism, identified with Judaism, is evil. The thesis that the essay is radically anti-Semitic is not new. It appears, for example, in Raymond Aron, Simon Doubnov and Isaiah Berlin. ${ }^{3}$ However, the geographer and marxologist Bensaïd, the biographer Wheen and other scholars refute the thesis of an anti-Semitic young Marx in 1844, and of that the antisemitism would have a role in converting Marx to communism. Bensaïd considers the charge of anti-Semitism in Marx a nonsense. ${ }^{4}$ Nevertheless, everyone agrees that the essay in question represents an indispensable step in the understanding of the young Marx's intellectual construction..$^{5}$

Nevertheless, those who refute the thesis of Marxian anti-Semitism cannot sustain the position, and new sources reinforces the suspicion that not only in 1843-44 was there an element of anti-Semitism in the writings of Marx, but of that this sentiment had played an essential in his conversion to communism. That is what this essay seeks to prove. For this, it is structured into four parts. In the first, one investigates the childhood of Marx and its intellectual formation in the college, the years as a student in Bonn and Berlin. In the second part, one carefully examines the trajectory of Marx as a journalist and a "Rhenish liberalism" adept. The section will demonstrate that he has not only failed to adhere to communism in its various versions, but also repudiated it as a superficial and inconsequential political alternative, lacking theoretical and philosophical foundation. The third section investigates the conversion of the young Marx to communism and links this process to the anti-Semitic flights on the manuscript in question. The last section, related to final considerations, supports and strengthens the thesis this essay defends. ${ }^{6}$

\footnotetext{
${ }^{1}$ The MEGA archive (Marx-Engels Gesamtausgabe) since 1920 has sought to make available to scholars everything that was published by Marx, Engels and the people who related to them. After the Berlin Wall fall, the Berlin-Brandenburg Science Academy, linked to the Marx-Engels International Foundation "[...] aims to publish everything Marx and Engels ever wrote, including the notes they scribbled on the backs of envelops." Sperber (2014, p. 12).

${ }^{2}$ Especially Sperber (2014), Jones (1017) and Heinrich (2018).

${ }^{3}$ Bensaï (2010-b, p. 75).

${ }^{4}$ Bensaïd (2010-b, p. 75): "From Roman Rosdolsky to Enzo Traverso, more serious readings examine, in the field of Marxist problematics, the ambiguities and gaps that gave rise to such nonsenses."

${ }^{5}$ Bensaïd (2010-b, p. 83-84): “Many vigilant readers, from Georg Lukács to Stathis Kouvélakis, through Auguste Cornu, Georges Labica, and Pierre Macherey, have shown that the 1844 article, far from constituting a separate theoretical object, is fully embedded in the formation of Marx's critical thinking."

${ }^{6}$ It is not intended to support the thesis that anti-Semitism played a major role throughout Marx's theoretical-philosophical system, as he would develop throughout life in the years after 1844.
} 


\section{MARX'S CHILDHOOD AND THE YEARS IN COLLEGE}

Marx is a descendant of a long line of rabbis from Trier. The intellectual elite of the city had a strong influence of the Enlightenment, strengthened with the arrival of the French. Those elite meets at the reading club in Trier, in which one of the members was Johann Wyttenbach, headmaster of the college where Karl was to study and who would certainly influence him. ${ }^{7}$ The situation of the Jews of Trier in two decades of a revolutionary and Napoleonic rule has improved considerably. The Jews imagined that they would now have a new position in the State and in society.

With Napoleon's so-called "infamous decree" of 1808, control was tightened on the Jews. Now they were obliged to obtain a "certificate of morality" to trade. As a way out, many Jewish families educate their children for more "fruitful" and "productive" occupations than lending money or acting as an intermediary. Aversion to the Jew did not change. In 1811, the Marx family moves to Osnabrück, north of Westphalia.

After the defeat of Napoleon, the Congress of Vienna (1814-15) reorganize Europe. Trier is now part of Prussia, the power in Berlin. Former French government officials are admitted to the Prussian service; especially also present in the judiciary. In 1814, Heinrich, the father of Marx, establishes himself as a lawyer in Trier. He's on the appellate court. Heinrich tries to get an authorization on an exceptional basis but is unsuccessful. He decides to change his religion. Between the late 1810 s and early 1820 s, most probably at the end of 1819 , he converted to Protestantism.

Converted Jews were accepted into the public sphere. At Trier itself, most of the members of the most prominent families of the Jewish community of the eighteenth century had converted to Christianity in the 1830s. The converted Jews did so mainly for fear of returning to the conditions of the old regime. Why did Heinrich become a Protestant and not a Catholic? Trier was Catholic, so he traded one minority for another. Karl's father was a convinced supporter of the Enlightenment. The rationalist ideas of the Enlightenment were better accommodated in Protestantism.

In 1814, Heinrich marries a young girl, Henriette Presburg, of a Jewish family, established in the Netherlands, whose family worked in the trade. Heinrich was in good financial condition, among the $3 \%$ of the richest families in the city, unlike the son who would live in economic insecurity. Karl did not attend primary school. He had private lessons. In 1830, he began his studies at the Trier Gymnasium. He studied classics, Greek and Latin. Marx's writings throughout his life, loaded with phrases or expressions in Greek and Latin, and with frequent allusions to the clas-

\footnotetext{
${ }^{7}$ On the influence of these events on the intellectual formation of Karl's father, writes Wheen (2001, p. 18): "[...] during the years of Napoleonic domination, he had become impregnated with French libertarian ideas about politics, religion, life and art, becoming 'a true eighteenth-century Frenchman' who knew Voltaire and Roussean by heart."
} 
sics, Greek mythology, etc., demonstrate the quality of teaching in this school. ${ }^{8}$ In the class, there were seven Protestants (there should be about 32 students). ${ }^{9}$ Protestants wanted to be government officials, military men, and other prestigious professions. Marx was a good student, not brilliant, good at German and Latin, and poor at mathematics. ${ }^{10}$ After Greek and Latin, he chose French as the third foreign language (not the Hebrew).

The father already imagines the son in the legal career, like him. The first writing of Karl Marx, of those that were preserved, was written for the discipline of German. There is in them an Enlightenment version of Christianity. The divinity as a moral light instead of a personal god. We note Kant's influences passed by director Wyttenbach. There is also the influence of the baron Johann von Westphalen, father of the future wife Jenny, who was an advisor of the Prussian district administration and friend of the Marx family. The topic of the essay is entitled Observations of a young person regarding the choice of the profession. ${ }^{11}$ Two aspects of the writing draw much attention: the opposition between obedience to which dictates the heart and "our relationships with society"; the other issue is the nature of the chosen function. The ideal profession must be "founded on ideas whose truth we are convinced of; [...] which offers the broader field in which to act, aiming at humanity," and which allows us "to approach the universal goal of completeness and perfection." Marx cites, as examples of an ideal profession, the academic one. No example in the professions most looked out by the middle class: military, administrator, business person or lawyer. The legacy left by the father, and reflected in the writing, is that intellectual life should function as a means of improving the human condition. Karl at the time was not a radical, he thought like his father (and his future father-in-law): liberal and rationalist.

In 1835, Marx begins his university studies. Initially, at the University of Bonn. Karl takes part in the League of Poets (including other future revolutionary leaders). Von Westphalen presents to Karl the works of Shakespeare, which became a lasting passion of the young person. ${ }^{12}$ The marriage proposal was Marx's first revolutionary act. ${ }^{13}$ According to his future father-in-law, Marx was "an excellent, noble and extraordinary boy." 14 The Jewish origin of Marx must not have disturbed him. Conservative evangelicals did not oppose to converted Jews. In 1836, Marx moves to the University of Berlin. In the first few months, he dedicates himself to writing poetry. The love for Jenny influences Karl's worldview and this is reflected in his

\footnotetext{
${ }^{8}$ Jones $(2017$, p. 59).

${ }^{9}$ Cf. Jones (2017, p. 57).

${ }^{10}$ Jones $(2017$, p. 59).

11 Translated from German to Portuguese in Heinrich (2018).

${ }^{12}$ Wheen (2001, p. 26).

${ }^{13}$ Sperber (2014, p. 62).

${ }^{14}$ Apud Sperber (2014, p. 63).
} 
romantic poetry. Attending law school, he attends jurisprudence classes taught by Professor Friedrich Karl von Savigny, to whom "the development of the laws and government of a country was an organic process that reflected the character and tradition of its people." He also knows an alternative view on these themes, disseminated by Eduard Gans, "a radical Hegelian who believed that institutions should be subjected to rational criticism, not to mystical veneration." 15

During his first year in Berlin, Karl does not prioritize philosophy, worried that he was going deeper into the study of Law. After some frustrated literary experiments, he encountered Hegel's ideas, "as intoxicating as the beer Marx consumed," 16 as stimulating as the love for Jenny. ${ }^{17}$ It is not known what led Marx, in those days, to embrace Hegel's philosophical system. Before, Karl had rejected Hegel's mermaid song, "whose grotesque and rough melody did not appeal to me," he said. ${ }^{18}$ On this occasion, Marx seems to have been "slightly unbalanced" to then discover affinities between his literary and philosophical experiments and the Hegelian system. In 1838, Marx finds himself ill at the death of his father. He knows financial difficulties with the death of him, but keeps the same "life disorganized and careless." 19 He contracts debts that would not be paid. The young boy leaves lectures at the university, gradually losing his enthusiasm for a career in Law. He thinks about his academic career and begins to work on preparing a doctoral thesis. Applies Hegel's methods in the study of the philosophy of Ancient times.

Marx receives influences from Eduard Gans, professor of legal history. ${ }^{20}$ Gans was a friend of Alex de Tocqueville. Gans also knew and taught Saint-Simon. However, he was not communist; he defended the cooperativism in the production. ${ }^{21}$ The main intellectual influence in Marx at the time was the Young Hegelians. They also provided the main personal and professional connections. They offered careful intellectual speculation and maintained a noisy, bohemian lifestyle. Very young and without the guidance of his now deceased father, Karl was becoming a radical in politics. Politically radical poets had also influenced Karl. In particular, Heinrich Heine.

Hegel offered the idea of a god who is nothing without his creation as opposed to the personal god of Protestantism. David Friedrich Strauss came to be known for his work The Life of Jesus analyzed in the light of theology, published in 1835. He was a Protestant pastor, a professor at the University of Tübingen, and is con-

\footnotetext{
${ }^{15}$ Wheen (2001, p. 30).

${ }^{16}$ Sperber (2014, p. 64).

${ }^{17}$ Among the young Marx's literary experiments, Wheen (2001, p. 32) cites the little entertaining novel Scorpio and Félix.

${ }^{18}$ Apud Wheen (2001, p. 33).

${ }^{19}$ Apud Sperber (2014, p. 72). See also Jones (2017, p. 61).

${ }^{20}$ Jones (2017, p. 87).

${ }^{21}$ Sperber (2014, p. 74).
} 
sidered one of the first young Hegelians..$^{22}$ Bruno Bauer, professor of Theology at the University of Berlin, develops in more depth, and contests, some aspects of Strauss's contribution. According to Bauer, this thinker was unaware of the importance of religious self-consciousness. ${ }^{23}$ The Feuerbach's The essence of Christianity is by far the most brilliant work of this movement. It generalizes the insights of Strauss and Bauer, and it masterfully applies Hegel's philosophy to a critique of religion. In his critique of the Christian religion, the believer attributes to a transcendent deity, mythical and supreme being, the best attributes of humanity as a species. A religious alienation takes place, in which the man departs from his essence by attributing all that is good to an outward being. Marx buys this idea, which would shape his thinking and actions. Now he is an atheist, who allegedly understands and contests the mechanism of his once Protestant religion in which he had been baptized. ${ }^{24}$

Another founder of the Young Hegelians is Arnold Ruge. He makes the connection among Protestantism, religious rationalism and Hegelian Enlightenment. With the Awakening movement of Frederick William IV, the educational and cultural policy of the Prussian government turns against the Hegelian doctrine and against its proponents. In reaction to this, the Young Hegelians become more radical, in the sense of more to left, however, the left understood in the liberal and republican sense, not in the communist sense. They collaborate with the liberal opposition in Prussia and defend, with great determination, democratic and republican ideals. Atheists and Democrats unite in the isolation imposed on them by official politics. Of the two, Karl was one of the atheists. He had Feuerbach as an intellectual model, but they never met, never worked together on an intellectual project. Feuerbach rejected Marx..$^{25}$ Of the leading Young Hegelians, Bruno Bauer most approached young Karl. The first one was both an assumed atheist and an advocate of republican ideas. ${ }^{26}$

It is possible that Bauer has inoculated anti-Semitism on Marx. More than a decade later, Bauer would be known as a conservative and an ardent anti-Semite. ${ }^{27}$ Karl had met Bruno in the summer of 1937 when he joined the Doctor's Club in Berlin, led by Bruno (although Marx was not yet a doctor). ${ }^{28}$ Marx is a protégé of Bauer, who had plans to insert him in the faculty of the University of Bonn. Encour-

\footnotetext{
${ }^{22}$ Jones (2017, p. 145).

23 Jones (2017, p. 113).

${ }^{24}$ Sperber (2014, p. 77): "This atheism, however, possessed certain traits of religion, since it involved the transference of God's sense of transcendence to humanity."

25 The reasons for this rejection will be set out below.

${ }^{26}$ Jones (2017, p. 115): "God was found exclusively in human consciousness. God was nothing more than self-consciousness, knowing himself actively."

${ }^{27}$ See Sperber (2014, p. 80).

${ }^{28}$ Wheen (2001, p. 33).
} 
age him to complete the thesis. Before trying his luck in Bonn, Marx concluded his doctoral thesis. It tries to compare the theories of the nature of the philosophers Democritus and Epicurus. The choice of Epicurus as the object of his studies is related to the abandonment of Marx of romantic influences, because "Epicurus was the most hated philosopher by the romantics, as the predecessor of French materialism of the eighteenth century and of a new mechanistic view of the world." 29 The thesis made a defense of idealism as a philosophy against "Democritus 'dogmatic' determinism based on nature" ${ }^{30}$ In Epicurus, but not in Democritus, "the atom contained something within it that allowed it to retaliate and resist the determination of another being, and this, according to Karl, was the beginning of a theory of self-consciousness." ${ }^{11}$ In a Hegelian way, Karl argued that Epicurus' doctrine represented an advance in the process of the intellectual development of humanity, and of man's self-consciousness. Indeed, Epicurus' ideas were a higher stage of thought, since they were closer to Hegel's view of the dialectical movement of self-consciousness, an opinion which opposed the non-dialectical conceptions of Democritus according to which concepts relative to the subject who thinks and perceives were employed to categorize the object of their perceptions, but did not present intrinsic connections with it. Bauer's influence on Marx convinced him that what evolves is not the absolute spirit, but human self-consciousness.

In the Preface of the thesis, seeking an analogy between the philosopher and Prometheus, of the Greek legend, he says he hates all religions. He is definitely an atheist Marx. The only deity admitted would be human self-consciousness. The question then is whether hatred of religions, besides applying to Christianity, would also apply to Judaism. Was Marx an anti-Jewish at this time? Would such a connection have any connection with anti-Semitism revealed in the 1844 essay, On the Jewish Question? We shall return to these questions later. He was a doctor. The thesis was accepted and approved in Jena. The date of approval is April 15, 1841. It was a doctorate at a distance, not face-to-face. ${ }^{32}$

\section{MARX LIBERAL JOURNALIST}

After the conclusion of his doctorate in philosophy, a reversal occurs in the pretension of Marx. He is unable to pursue his academic career and begins to devote himself to journalism. Marx would have no chance of being accepted into the career in Bonn after the resignation of his "tutor", Bauer, in March 1842. Marx is now 23

\footnotetext{
${ }^{29}$ Jones (2017, p. 101).

${ }^{30}$ Jones (2017, p. 102). Vide Wheen (2001, p. 38).

31 Jones (2017, p. 103).

32 The University of Jena was the only one that did not require a period of residence and a formal defense before a board.
} 
years old and unemployed. Nevertheless, already with the title of doctor. He finds a new professional perspective acting as a critical journalist and protester in the press who opposes the Prussian State. By this time, Karl had hoped to benefit from the estate of his dead father, but his mother had discounted the part he would have to receive from the massive sums he had received in recent years. He was "exposed to the most miserable conditions". ${ }^{33}$ His relationship with the family of origin deteriorates. Conflict with his mother and brothers may have reinforced anti-Judaism as a criticism of the belief system of religion, and perhaps brought him closer to antiSemitism, attributing to his mother's apparent avarice, and her insistence on accounting, a stereotypical Jew trace (money worshiper, usurer etc.).

After a failed attempt to establish himself in Cologne, Marx spent the year 1842 in Bonn. ${ }^{34}$ Meanwhile, his friend Bauer makes some success with the launch of the satirical pamphlet The Trumpet [The Trumpet of the Last Judgement against Hegel the Atheist and Antichrist: An Ultimatum] which make many references to the Jacobins. ${ }^{35}$ Marx had not worked on this pamphlet, but on a continuation of it, which was never published, concerning the Hegelian and Christian arts, attacking German Romanticism, with its anachronistic medieval remnant.

Everyone saw Marx as an equally subversive collaborator of Bauer. The dismissal of this, therefore, closed the doors of the university environment. Without a job, he could not marry Jenny. The only way he could glimpse was by acting as an independent writer, as opposed to the Prussian State. Karl had been involved in the collaboration in a newspaper in the Rhineland, the Rhine Gazette. There is no doubt that the experience with this newspaper was decisive in his intellectual development since was able to exercise political activism. ${ }^{36}$

Marx acts in this newspaper from October 1842 until mid-February 1843. Radical intellectuals from all over Europe come to see him not as a pupil of Bruno Bauer, but as an author of own merit, a great polemicist. At the same time, the Prussian authorities begin to see him as a subversive and dangerous agitator. Marx is recognized as a notable writer by the well-to-do bourgeoisie of Cologne. Moreover, he also captures the admiration of other segments of society. Marx was finally rewarded for his student efforts and began to nurture a serious pretense in journalism of political engagement. What did he publish in this periodical and what attracted the admiration of the public? First, the article on freedom of the press was successful, then an article (published in MEGA), formulated in a defensive tone and dealing with the atheism of the young Hegelians appears; trying to calm the religious sensibility of the Catholics of the Rhineland. The fact that Marx's two essays were praised by broad sections of the literate population already induces

\footnotetext{
33 Sperber (2014, p. 86).

${ }^{34}$ Marx would eventually establish himself as a journalist in Cologne, working in the Rhine Gazette.

35 Jones (2017, p. 123) writes that in The Trumpet "Hegel became an apologist for Robespierre."

${ }^{36}$ Sperber (2014, p. 92).
} 
that their content was in fact non-radical, essentially humanitarian and conflict management. There is nothing of the radical and communist person as would be remarkable in the following years. Conversion to communism does not begin there; but throughout the year 1843, in the months in which he was no longer active in this newspaper.

The Rhine Gazette emerged to break the monopoly of the only newspaper of great circulation in the Rhineland, the Cologne News. Two radical young intellectuals, rich enough, took up the task of implementing the newspaper: Robert Jung and Moses Hess. Hess was critical of the Young Hegelians and probably influenced Marx to move away from Bruno Bauer, who in the following years would change from tutor to great intellectual adversary. Hess reinforces in Marx the ideas of the communists Henri de Saint-Simon and Charles Fourier, which he had known since the gym in Trier. However, there was no conversion to this communist belief by Marx. This French-style communism was not in keeping with the ideals of the young Marx, still a Republican, liberal, with a strong humanitarian and essentially atheistic appeal. The communism of the time was permeated with a religious aura. ${ }^{37}$ It was very close to Christian doctrine.

Marx sees these ideas and hopes with some disdain. He was not communist in 1842; although one of the newspaper's founders, Hess, was that. The other founder, Jung, and most of those who supported the Rhine Gazette were liberals, acting politically to destroy authoritarianism and the bureaucratic obstacles of the Prussian government. The capitalists, who supported the newspaper, prevented Hess from assuming its editorial. Such capitalists naturally had no interest in promoting Hess's idea of the abolition of private property. By then it seemed the newspaper would open up to Bauer's militant atheism. In addition, Arnold Huge and several members of the Doctor's Club came to collaborate for the Rhine Gazette.

It is important to point out the two long essays written by Marx and published in that newspaper in 1842. A more inflamed, sarcastic and polemical style is now perceived, which would characterize his writings from then on. ${ }^{38}$ In the first published treatise, Marx reveals an affirmative style, praising freedom of the press as part of a wider praise for freedom. He looks more like a liberal libertarian than a communist. The defense of liberty is made in line with the ideas of the Enlightenment and the French revolutionaries of 1789, as one of the fundamental rights of man. Marx seems a revolutionary holding idea of the Enlightenment and attacking the old order society. ${ }^{39} \mathrm{He}$ also praised democracy.

The Rhine Gazette was accused of trying to replace Christianity with contemporary philosophy. The newspaper's founders, Hess and Jung, support Marx's appointment as editor. Hess had known Marx the previous year when Karl had re-

\footnotetext{
${ }^{37}$ Jones (2017, p. 170).

${ }^{38}$ Jones (2017, p. 130) and Sperber (2014, p. 96).

${ }^{39}$ Sperber (2014, p. 100).
} 
turned to Rhineland, and Hess had been rather impressed by the young man. ${ }^{40}$ In October 1842, Marx takes the post of assistant editor. The most important thing for Marx is that for the first time in his life he signed an employment contract. With this position, he could finally consummate the marriage with his Jenny. As an editor, Marx came over the liberal members of the bourgeoisie. In addition, he opens space for contributors with more moderate political inclinations. Clearly now the Rhine Gazette had become a liberal newspaper. ${ }^{41}$

At the same time as he approached the liberal ideals, Marx moved away from the Young Hegelians. Under the influence of Hess and Ruge, he breaks with Bruno Bauer and begins to attack those young people. Marx had realized that criticism of religious orthodoxy was not the point; the best strategy would be to attack the social and political circumstances that stimulate and reinforce this orthodoxy. A general plan that would characterize Marx's work from then on is already unfolding: to extend criticism of religion toward criticism of society, State, politics, and economics. He would then write two articles about the debates on the laws against theft of wood held at the provincial assembly.

The central thesis of the essays is not communist. Drawing on his training in Law, especially under Professor Gans' teachings in Berlin, Marx saw the theft of wood as a result of the changes in the legal nature of the property. Young Karl was defending a liberal view of the common law, and that by collecting wood in the country the villagers were only obeying an established tradition. ${ }^{42}$

The period as editor of the Rhine Gazette brought Marx closer to the social question, to the debate on the condition of the less favored classes. It is likely that the genesis of communist ideas is linked to this concern. Nevertheless, there is something more fundamental involved in the conversion of Marx, as we will explore later. In addition, we believe that this was even more important in shaping Marx's anti-capitalist ideas than his concern for the poor. Marx had already been introduced to the theories of Saint-Simon, in his early youth at Trier, by Baron von Westphalen, and then by Professor Gans in Berlin. However, Marx, in 1842, was anticommunist. ${ }^{43}$ Even in the communist phase, beginning in 1843, Marx would continue to oppose many aspects of communism he had learned the previous year. Communist ideas made a negative impression on the young Marx of 1842 . He associated such ideals with the Young Hegelians of Berlin with a radicalism and a typical lifestyle that Marx now rejected. ${ }^{44}$

\footnotetext{
${ }^{40}$ Sperber (2014, p. 103).

${ }^{41}$ Jones (2017, p. 134).

${ }^{42}$ Without being Communist, the young Karl advocates the revision of the right of agrarian property in order to accommodate to the agriculture of subsistence of the peasants. See comments on Jones (2017, p. 45).

${ }^{43}$ Sperber (2014, p. 108): "His initial public pronouncements on the subject of communism were far from favorable; in fact, were notably anti-Communist “. See also Jones (2014, p. 164) and Wheen (2001, p. 48). ${ }^{44}$ Sperber (2014, p. 109).
} 
As an editor, he began to reject the articles of these Young Hegelians. ${ }^{45}$ Marx writes in an article published in the Rhine Gazette: "[...] I demanded of them a completely different and deeper discussion of communism if there is a need for discussion." "Marx was referring to and criticizing the two papers published in the newspaper in defense of communism, of the end of private property. Instead of adhering to this banner, Marx offered an arsenal of liberal criticism of the prevailing conditions in Germany, blamed State intervention and bureaucracy for the situation. One of the arguments against communism, launched in its reply, is wellknown. He said that the newspaper does not recognize any theoretical reality in communism, even less any effort towards practical realization. The intellectual implementation of communism would be a danger, as this could "defeat our intelligence, dominate our feelings". ${ }^{47}$ To face this danger, he proposed a careful study of the work of prominent communists, a study he had not yet done. ${ }^{48}$

Marx thought of social issues on the model of nineteenth-century liberalism, pro-capital and pro-free-market, perhaps more concerned with the poor than other liberals did. In his role as editor of the newspaper, he revealed his journalistic aptitudes, his polemical talent, "which inspired his friends and infuriated his enemies." ${ }^{49}$ Despite the success of his publications and praise for his role as editor of the newspaper, he tired of all his efforts to appease the authorities, to avoid criticism and cuts of the censor. Even moderate ideas were censored. Frustrated, he writes to Ruge. ${ }^{50}$

\section{COMMUNIST AND ANTI-SEMITIC MARX}

Ruge offers Marx a job on the editorial in the newspaper to be published in France, the Franco-German Annals. Financial support for a bourgeois life was settled. After the employment contract, Marx travels with his bride, accompanied by a small entourage, to the seaside resort of Kreuznach in order to marry. After the honeymoon, they remain in Kreuznach until the middle of October, before departing for Paris. In these early months of marriage, Marx had free time to devote himself to intellectual work and write a critical analysis of Hegel's Philosophy of Right. Critique of Hegel's Philosophy of Right, in addition to presenting Hegelian reflections on the law, deals with political issues, already been worked while editor

\footnotetext{
${ }^{45}$ Wheen (2001, p. 48).

${ }^{46}$ Apud Sperber (2014, p. 109).

${ }^{47}$ Apud Sperber (2014, p. 111).

${ }^{48}$ Bensaï (2010-a, p. 11).

${ }^{49}$ Sperber (2014, p. 117). See Wheen (2001, p. 52).

${ }^{50}$ See the letter to Ruge in Jones (2017, p. 143). In this letter, Marx communicates his departure from the Rhine Gazette, which in any case had been closed by the government.
} 
of the Rhine Gazette in the previous year, now under the strong influence of Ludwig Feuerbach's doctrine. Feuerbach's point borrowed by Marx is a new idea of alienation. Like Bauer, Feuerbach had extended the process of projecting human characteristics into a supreme, imaginary being by externalizing, emptying, and alienating man as a genre. The same kind of projection of collective human characteristics into an imaginary entity, a deity, could also be identified in the absolute spirit of Hegel, the driving force of nature and history. However, Feuerbach, unlike Bauer, did not think that only consciousness or self-consciousness was being alienated. The human genre, in its material and natural existence, in sensory existence, alienated itself in religion. Feuerbach was a materialist; he saw the existence of man, above all due to primary natural processes, such as meeting basic needs. Marx, though enchanted with Feuerbach's materialism, thought that man should not be conceived essentially in his natural relations, for in addition to references to the biological nature of man one must study its political nature. The real man is the one who acts in civil society, who toils and participates in exchanges, who that seeks to keep himself. ${ }^{51}$ The citizen is only a predicate, an idealization made real in the idea of the Prussian national State as the apex in the development of an idea, of rationality, which reflects the absolute spirit in its stage of development. ${ }^{52}$

Notice how these philosophical reflections flow into a particular vision of democracy. Democracy is not the republic, an abstract form of State that is opposed to the monarchy. Democracy is the regime of popular sovereignty in which concrete men act. As a private group, individuals are committed only to their own interests (properties and contracts). There is a contrast between the private sphere and the State. The latter is a form of organization of these private lives, responsible for promoting the universal laws that govern such lives, but which lacks the same content that these lives have. In existing societies, there is an opposition between these two spheres of interest, but Marx speculates on the conditions in which the State would no longer oppose the private interests of civil society.

$\mathrm{He}$ is writing that democracy has a necessary content not fulfilled by the republic, an abstract form of State. For the democratic State, it might be necessary to promote social change..$^{53}$ There are slight indications that such changes would be the revision of the regime of private property. However, Marx does not exploit this. In these months of 1843 , his opinion on democracy is indefinite and may require a revision of existing provisions regarding property rights. There must be a regime in which the specific and private interests of civil society articulate simultaneously with the universal common good since both are manifestations of the people.

What is important is to emphasize that the thesis of communism as a political and social ideal does not yet appear. Just a particular vision of democracy. Such a

\footnotetext{
${ }^{51}$ Jones (2017, p. 135).

52 Sperber (2014, p. 123).

${ }^{53}$ Bensaid (2010-a, p. 11) clarifies Marx's type of revolutionary appeal contained in the critique of Hegel's philosophy of law.
} 
view is still compatible with liberalism, but there is a dangerous implication that perhaps the State should interfere in the sphere of private rights in order to provide the expected harmony between the public and the private. Marx had by no means provided the formula for how a new political and social order would come into existence. The solution by way of communism had not been explored. The first months in Paris, in the editing of the Franco-German Annals, would change this view, leading the young Marx to adhere to the formula of communism.

Marx was willing to attend secret Parisian societies composed not only of illiterate artisans. ${ }^{54}$ Between October 1843 and the beginning of 1844, Marx became a revolutionary communist. His trajectory, the shift to Paris full of leftist agitators explains in part this transformation. However, in this essay, we will identify the key triggering factor of a process that we can describe as a true conversion. Marx was already a mature thinker and would not adhere to any intellectual movement without much greater insight than had occurred in Berlin in his student years. ${ }^{55}$

During the summer he spent in Kreuznach, Marx developed extensively the application of Feuerbach's philosophical approach to a critique of Hegel's political philosophy. To this end, not only the philosophical insights found in The Essence of Christianity contributes, the work that made Feuerbach famous in 1840, but also the reading by Marx of the essay of Feuerbach published in Ruge's journal (Anekdota): Preliminary Theses for the Reformation of Philosophy. In this essay, the philosopher maintains that the human being was not only a thinking being but also a man in nature, who in addition to personifying reason and freedom, was fundamentally a "sensual being". As a natural being, he needs the other one, of his love, the basis of the elemental relationship of the species. The first object of man is the man, writes Feuerbach. The "creature of needs" depends on others; he/she is a communal being. The action of other men leads to individual self-consciousness as the consciousness of universal humankind. The isolated being conceives himself as a being-species. In this view, the primacy of gender over the individual is defended, of the human species over the individual representative. Such a formula would mark one of the central aspects of Marx's thought. Yet at this stage of the evolution of his thought, Feuerbach's construction of the being-species leads him to a critical revision of the meaning of the Hegelian concept of civil society. Hegel only thought of it as a sphere of necessity, the field of the exercise of selfish desires, the forms of exchange and independence of economic agents. Marx sees it as the capacity to become the true sphere of human freedom. Nevertheless, to this end, the individualism of modern society should be combated. Religion had been pointed out as the major responsible for this individualism by transforming the com-

\footnotetext{
${ }^{54}$ In general, they were led by veteran leftists of intellectual formation who defended communist ideas. See Sperber (2014, p. 129).

55 Jones (2017, pp. 145-146) explores the causes of the birth of the communist Marx.
} 
munal character of the species-being into a particular union of each individual with an external being. ${ }^{56}$

Marx thought that Feuerbach paid too much attention to nature and less attention to politics, and from then on sought an ambitious extension of his criticism. ${ }^{57}$ If the essence of each individual falls into its social quality, the State must be conceived as a way to be and mode of action of that quality. If Feuerbach had said that it is not religion that creates man, but the man who creates religion, Marx extends this inversion by applying it in politics: it is not the Constitution that creates the people, but the people who create the Constitution.

The February 1844 edition of the Franco-German Annals was the only one in the new publication. The newspaper had failed as a business, but Karl in the work of the two published manuscripts of his authorship could take an important step in shaping his worldview, toward his version of communism. In Marx's Introduction to the Critique of Hegel's Philosophy of Right, he professes his faith in the proletariat. ${ }^{58}$ In this manuscript, Marx begins to develop, for the first time, a theory that explains how the political and social transformations that he imagined should be realized. In order to do so, he had chosen an agent of this transformation, a social class that would have the role of driving the whole process: the poor workers, generally under-educated and involved in the factories, to whom he employed the well-known term, at the time considered pejorative, "proletariat". ${ }^{59}$

Where did Marx get this idea from choosing a class, a people within the general population, to lead the revolution? Clearly, the idea has religious echoes and refers to the notion of chosen people of the Jewish tradition. Judaism appears as a "ghostly specter," to use a metaphor typical of Marx, in another article published in the same issue of the newspaper: On the Jewish Question. Written right at the time of Marx's conversion, it seems to be the key to unraveling the origin of his creed. ${ }^{60}$ There is in the essay an economic and social critique connected with the posture of the Jews in society. Marx reveals an anachronistic conception of antiSemitism. Anti-Semitism was the fundamental step in the direction of Marx's anticapitalism and would guide him, at least at this moment, in the construction of his

\footnotetext{
${ }^{56}$ Jones (2017, p. 148).

${ }^{57}$ Philosophers should descend and engage in current practical issues. This is perhaps the main motive for Feuerbach to have rejected Marx, as we said earlier. For Feuerbach, it would be reckless to move from theory to practice as long as the theory would not have been perfectly carved.

${ }^{58}$ Cf. Marx (2005, p. 162).

59 The friend of Marx's father, Johann Heinrich Schlink, had already used the proletarian name to describe the class of the poor who reproduced numerically. The fear was that the masses of the poor could one-day rebel against their miserable fate by resorting to violence. Marx himself had shown remnants of this fear in the period when he was editor of the Rhine Gazette.

${ }^{60}$ Bensaï (2010-a): “On Marx's Jewish question marks a turning point in his intellectual and political change."
} 
theoretical system against capitalism and its political action for the cause of revolutionary communism.

The conversion to communism was not by a humanist impulse, through solidarity with the poor that Marx had known in Paris. In Marx's Introduction to the Critique of Hegel's Philosophy of Right, he chose as his "people" a proletariat conceived in a fundamentally theoretical way, he had not identified himself with the real poor. ${ }^{61}$ In his essay, he advocates that social circumstances should be changed in a drastic, revolution-nary and violent manner. It is not enough just the theoretical criticism, the reflection. ${ }^{62}$

The proletarian class was chosen in a mythical way as the force of change that would act behind the scenes and would become the master of history as a successor to Hegel's absolute spirit. Marx only imputed this role to an abstractly conceived class. ${ }^{63}$ The aspirations of Marx, who was an adept of Enlightenment ideas, a liberal man, in a manner of speaking, reached a point where the achievements of the French Revolution, the popular revolution and with democratic pretensions par excellence, were not enough for emancipation and human happiness. What had gone wrong with the revolution now regarded as merely bourgeois? The answer seems unequivocal: it had not prevented men from living in their private egoism, because it had been only a political revolution distinct from the radical revolution. ${ }^{64}$ The forms of domination and oppression, which were direct and explicit, became indirect and undercover domination in bourgeois society. ${ }^{65}$

Taking up the issues and problems discussed in the body of Hegel's Critique of Philosophy of Right, tensions between the public sphere and the private sphere could only be resolved by combating private property. Marx begins to signal in this sense but did not go ahead in that work. Now he says in the Introduction of the same work, written after the communist conversion, that it is necessary to subvert this order by acting in the private domain, subverting the rules of civil society. Why is it necessary to finish with private property? The point is that the young Marx of early 1844 supports the communist ideology with an essentially moral argument: it is not possible to reconcile the public and the private because in the private sphere men are incorrigibly egotistical. Moreover, this selfishness produces more and more inequality. Such human inequality could be mitigated, but the force of laws cannot counteract it. This is because the laws of the bourgeois state only delimit the field

\footnotetext{
${ }^{61}$ Sperber (2014, p. 130): “Marx's personal affinity with the true working class and with the suffering, actions, aspirations, and ideas inherent in it was hardly beginning when he placed in his class his revolutionary hopes."

62 See Marx (2005, p. 157).

${ }^{63}$ Bensaid (2010-a, p. 17): "The class that emerges [the proletariat] is still only a conceptual hypothesis which is supposed to respond to the enigma of modern revolutions".

${ }^{64}$ Bensaïd (2010-b, p. 91). See Marx (2010, p. 53).

${ }^{65}$ Heinrich (2018, pp. 23-24): "Instead of personal relations of domination enter, under capitalist conditions, the impersonal, objective ones - the mute coercion of economic relations..."
} 
in which men can act as selfish, for example demarcating property rights, but cannot eliminate the deleterious effects of this selfishness. ${ }^{66}$ Marx, in the essay On the Jewish Question, separates the rights of man from the rights of the citizen. The republican constitution of the French takes the bourgeois as the man and assures him rights that represent only the right to the separation of the others. ${ }^{67}$

Although the liberal constitution of human rights, which followed the French Revolution, secures such rights and eliminates the system of orders treating all as equals, it does not go beyond the effort to prevent greed, usury, unbridled pursuit of profit and other scourges popularly attributed to the free-market system. Acting in civil society it no longer harmonizes with the objectives of the State, of the truly democratic order envisaged by Marx. It is necessary to attack the right of property.

Criticisms of Hegel's political philosophy moved Marx toward the decisive formula of communism; however, one could not rely solely on these constructs, which sought to reconcile individual man and abstract citizen, individual human being and species-being, social power and political power, since in political philosophy Marx's intellectual developments up to that time are indeed incomplete and with serious gaps. ${ }^{68}$ Marx's orientation of thinking individuality only as a departure from the social being ends up completely dissolving the individual human being in the human genre, in the species-being. ${ }^{69}$ In the essay On the Jewish Question, his actor criticizes the bourgeois notion of man as sovereign individuality, which does not become a generic entity. ${ }^{70}$ The hope of the young Marx is that man finally emancipates and becomes "a generic entity in the quality of individual man in his empirical life, in his individual work, in his individual relations..." 71

The opposition to capitalism in the young Marx is essentially of a moral nature. Universal human emancipation involves the end of capitalism. This is because capitalism is bad, argued the young Marx. However, why is it evil? Because bourgeois society isolates men, it totally delimits the sphere of private action, and in this sphere, grants each one the right to exercise his evil, his selfishness. The guarantee of liberty and rights to the bourgeois is the security offered by the State so that they

\footnotetext{
${ }^{66}$ See Bensaïd (2010-b, p. 91).

${ }^{67}$ See Marx (2010, p. 48).

${ }^{68}$ G. S. Jones (2017, p. 157) is accurate in his remarks: "Whatever the validity of Karl's attempt to theorize not just Hegel's State but the modern State itself, the result was a rigid and impoverished theory in which the differences between the Prussian State and the US State, for example, have become secondary rather than essential. Second, the supposed alternative between the separation between civil society and political state, between man and citizen, rested on a totally uninvestigated view of the 'social character' of human nature and the 'universal character' of the individual, supported only by a fleeting reference to the Greek polis."

${ }^{69}$ A scholarly, deep, and consistent criticism of Marx's annulment of human individuality in the name of the humanist presupposition of generic man appears in Calvez (1959). See Bensaïd (2010-b, p. 92).

${ }^{70}$ Cf. Marx (2010, p. 45).

${ }^{71} \operatorname{Marx}(2010$, p. 54).
} 
should only worry about the small world around them without being compelled to act charitably for the common good. Private property separates men, makes them selfish, suppresses community sentiment, and makes each one see in the other only an obstacle. In On the Jewish Question, he writes: "That individual freedom [...] makes every man see in the other man, not the realization, but on the contrary the restriction of his freedom [...] Therefore, none of the so-called human rights transcends the selfish man, man as a member of bourgeois society, namely, as an individual picked up to his private interest and private caprice and separated from the community [...] The only bond that unites them is a natural need, the lack and the private interest, the preservation of their selfish property and person." 72

Now, what harm is there in men being selfish? The question is pertinent because one is not here to analyze Marx's moral philosophy, but his writings of a political and economic nature. Adam Smith and several eighteenth-century economists and thinkers argued that egoism is not necessarily detrimental to the functioning of society. The formula "private vices, public benefits" was well-known at the time of the young Marx, and he certainly knew that self-interest could be beneficial to society. Indeed, Marx would need an exogenous element to reinforce the thesis that men are as if poisoned by capitalism. What is the origin of this poison? The young Marx mysteriously had been convinced, at the end of 1843, that the Jews were the cause of all this evil. ${ }^{73}$ Where did he get that? How did he arrive at this indecorous conclusion? After all, Marx was from a not only Jewish family but a rabbis grandfather one.

Authors such as Werner Blumenberg, Arnold Künzli and especially Volker Elis Pilgrim claim that after the baptism of Marx's father there would have been a rupture between the father and his family. Michael Heinrich claims there is no document proving a break with the family and some sense of guilt. However, the anti-Semitism demonstrated by Marx in On the Jewish Question induces to think that the relationship with the Judaism, and with the Jewish family, would not have been very peaceful and lovely. It is suspected that the Christian conversion has produced some shock in the family. ${ }^{74}$ Pilgrim is convinced that, according to religious rules, the abandonment of religion means social death. Nevertheless, it seems that Heinrich's case was not so drastic. Biographer Michael quotes amiable letters exchanged between Marx's father and relatives of the family of origin. On the other hand, Pilgrim remembers the letters exchanged between the father and the son Karl, in which the first one complains of loneliness. Some biographers believe that the humiliation of having to be baptized would have provoked in the father a yearning for compensation in the most intelligent son. In fact, Heinrich spared no expense in his son's education, always sending him to the best schools. In the letters

\footnotetext{
${ }^{72} \operatorname{Marx}(2010$, p. 50).

${ }^{73}$ According to Muller (2011, p. 56), Marx's view of capitalism, using stereotyped images of antiSemitism, is completely archaic. See also Wheen (2010, p. 58).

${ }^{74}$ Cf. Jones (2017, p. 29).
} 
to the son, he writes: "his high ascension, the flattering hope of seeing his name famous a day [...] are illusions long stoked, deeply established." 75 However, Karl must not have reacted well to the enormous pressure of the family for a successful career in the field of Law. The somewhat erratic trajectory in the university and the bohemian lifestyle seem to indicate that he sought other paths, refusing to follow the footsteps outlined by his father. ${ }^{76}$

Even speculatively, we are forced to explore some traits of the young Marx's personality that might give clues to his conversion to communism in 1844. The famous written essay at the end of high school suggests a striking personality trait: the identity of being the savior of humankind. ${ }^{77}$ At the stage in Bonn, it is evident from several of his later poems the disdain for the vulgar man, the ignorant with little culture that is dedicated to practical activity, to business in commerce, called the "Philistine." ${ }^{78}$ Marx then begins to associate the bourgeois with the Philistine. Prejudice to practical activities can easily turn into prejudice against capitalism. Prejudice to the Philistine turn in hatred of the stereotyped Jew, usurer and moneyworshiper, who does not care about anything else.

Where did the young Marx rescue the monstrous caricature of his own people, as people who only care about the gain in trade and finance? Even because his family was rabbis, they all had some small business, but they were mainly devoted to the study of the sacred books of Judaism, like any rabbi, or else we have the figure of the father, a serious Law scholar. Something must have marked the trajectory of the young man that led him to write the execrable anti-Semitic invectives in On the Jewish question. In this book, one can read: "What is the secular basis of Judaism? Practical need, self-interest. What is the worldly religion of the Jew? Huckstering. What is his worldly God? Money. [...] We recognize in Judaism, therefore, a general anti-social element of the present time [...] The Jew has already emancipated himself in a Jewish manner, not only because he has acquired financial power, but also because, through him and also apart from him, money has become a world power and the practical Jewish spirit has become the practical spirit of the Christian nations. ${ }^{79}[\ldots]$ What, in itself, was the basis of the Jewish religion? Practical need, egoism. [...] The god of practical need and self-interest is money. Money is the jealous god of Israel, in face of which no other god may exist." ${ }^{80}$ In Marx's revealed anti-Semitism, money and financial assets are the mundane gods of the

\footnotetext{
75 Apud Pilgrim (1992, p. 228). See Jones's comments (2017, pp. 57-56).

${ }^{76}$ See Bensaïd (2010-b, p. 76).

${ }^{77}$ Karl Marx, Considerations of a boy about choosing a profession [in Portuguese: Considerações de um rapaz acerca da escolha de uma profissão], in Heinrich (2018, p. 424). Jones (2017, p. 59) writes that in this essay "Karl demonstrated a quasi-religious sense of vocation."

${ }^{78}$ Jones (2017, p. 66): "In later poems, a battle against the world is invoked, but it is the battle of the poet or the artist against the Philistines or bourgeois."

${ }^{79} \operatorname{Marx}(2010$, p. 56).

${ }^{80} \operatorname{Marx}(2010$, p. 56).
} 
Jews, and bargain is their mundane religion. The secular basis of Judaism, allegedly, is practical necessity and self-interest. Marx explains that Judaism as bargaining had developed throughout history until money became a world power and the cult of Mamon (sic) became universal.

In his anti-Semite essay of 1844 the Jew is accused of "believing that he has the right to isolate himself from humanity by not taking part in the historical movement by principle, by waiting for a future that has nothing to do with the general future of man, by considering himself a member of the Jewish people and having the Jewish people in charge of the chosen people." 81 He condemns the Jew for isolating himself from society in general, just as Marx condemns the bourgeois who moves away from others, who acts independently in the private sphere, without prioritizing the interest of the others, the benefit of the community. The egoism of the Jew who sees himself differently from the rest of the other religions is approximated to the egoism attributed to the bourgeois in the economic sphere. Judaism, according to Marx, was the religion that legitimized capitalist practices. The mere political emancipation could not emancipate the Jew. Only human emancipation with communism would emancipate man from bargaining and money. In communism, the Jew becomes impossible. ${ }^{82}$

\section{FINAL CONSIDERATIONS}

Even if in criticism of the practical sense Marx moves away from the Jew, in another respect he remains deeply attached to his people. He had the studious behavior of a rabbi who devoted himself wholeheartedly to study and doctrine. However, Marx does not seek his doctrine in the Torah and the Talmud, but in philosophical studies and in the creation of his theoretical system. ${ }^{83}$ It is also impressive that in the same publication of the Franco-German Annals Marx announces the discovery of the proletariat, taken as a people of Israel, to which he, Moses, could show the way of exile, towards the promised land of communism.

Marxists refuse to engage in further debate on the meaning and implication of the anti-Semitic insults contained in On the Jewish Question. ${ }^{84}$ The defenders of the young Marx see no traces of anti-Semitism in him, only rhetorical exaggerations

\footnotetext{
${ }^{81} \operatorname{Marx}$ (2010, p. 34).

82 On Marx’s criticism of the Jew, see Pilgrim’s observations (1992, p. 240).

${ }^{83}$ See Bensaïd (2010-b, p. 76).

${ }^{84}$ Jones (2017, p. 187) asserts that "Understandably, commentators have treated 'On the Jewish Question' with some clumsiness, not least because of the thoughtless and uncritical use of anti-Semitic images." Mary Gabriel (2013, p. 85) in his excellent biography in the form of romance of Marx in family offers virtually no comment on the astonishing anti-Semitic content of the essay published in the FrancoGerman Annals.
} 
in the essay. ${ }^{85}$ They argue that Marx wanted to give his opinion on the emancipation of the Jews, on granting them equal rights before the law. Marx was criticizing and opposing Bruno Bauer's thesis, now turned into his intellectual adversary, on this issue. ${ }^{86}$ In this sense, Marx only kept the tone offensive to the Jews of his opponent, even though he was one of them, did not try to defend his people. Or rather, he defended them in a sense: unlike Bauer, he was in favor of the equality of Jewish rights. ${ }^{87}$ Marx's ambivalent stance does not exempt him from anti-Semitism. The defense of the emancipation of the Jew was only an opportunism because the very reasoning that gave the Jews equal rights justified the demand that society undergoes a transformation towards communism.

Marx advocated a secular State, and this emancipation of the State would, on the other hand, represent the political emancipation of religious persons. ${ }^{88}$ Contrary to what Bauer thought, for Marx particular religions would not have to absorb modern, Enlightenment ideals. The very secularization of the State would eliminate religion from politics and public life, however, it would preserve freedom of belief in individual choices. Marx writes: "The emancipation of the State from religion is not the emancipation of the real man from religion." 89 Religious beliefs, in any case, would be eliminated when the secular State, in addition to guaranteeing equality before the law, also seeks to eliminate private property. The end of private property would suppress economic alienation, and thereby the forms of religious alienation that bind to it. ${ }^{90}$ Marx's formula sums up that money and religion (not just Jewish faith) alienate humankind from itself, from which "the emancipation of the Jews amounts ultimately to the emancipation of humanity from Judaism." 91 Replacing here "Judaism" with "capitalism" the meaning of it is completely revealed. Judaism for Marx is egoism applied to commercial life, to economic relations. Essentially capitalism was seen by him as an expression of Judaism, the application, in a social and economic system, of the principles of Judaism based on selfishness and practical needs.

It is noted that criticism of Judaism differs from criticism of religion in general, Christianity in particular. Both are accused of separating and isolating people: "man is constituted as religious [...] to the extent that, in this case, religion represents the spirit of bourgeois society, the expression of division and detachment between people." ${ }^{92}$ However, Marx fundamentally associates Judaism with the overly practi-

\footnotetext{
${ }^{85}$ Cf. Wheen (2001, p. 59), as an advocate of Marx.

${ }^{86}$ Bensaïd (2010-a, p. 18).

${ }^{87}$ For Bauer, Jews would only have equal rights when they had renounced Judaism. Bensaid (2010-a, p. 18).

${ }^{88}$ Cf. Marx (2010, p. 38).

${ }^{89} \operatorname{Marx}(2010$, p. 46).

${ }^{90}$ Bensaïd (2010-a, p. 21).

${ }^{91}$ Marx (2010, pp. 56-60).

$92 \operatorname{Marx}(2010$, p. 45).
} 
cal, material-oriented, orientation he condemns. Moved by the formula that "criticism of religion is a prerequisite of any criticism," Marx refused to study and understand the nature of the religious impulse. Religion was just an anathema..$^{93}$

\section{REFERENCES}

Bensaï, Daniel (2010-a) “Apresentação: Zur Judenfrage, uma crítica da emancipação política.” In: Karl Marx, Sobre a questão judaica. São Paulo: Boitempo.

Bensaï, Daniel (2010-b) Posfácio: “Na e pela história.” Reflexões acerca de Sobre a questão judaica.” In: Karl Marx, Sobre a questão judaica. São Paulo: Boitempo.

Calvez, Jean Yves (1959) O Pensamento de Karl Marx. Porto: Editora Tavares Martins.

Carvalho, Olavo de (2015) O Jardim da Aflições: de Epicuro à ressurreição de César: ensaio sobre o Materialismo e a Religião Civil. Campinas: vide Editorial.

Gabriel, Mary (2013) Amor e Capital: a saga familiar de Karl Marx e a história de uma revolução. Rio de Janeiro: Zahar.

Heinrich, Michael (2018) Karl Marx e o nascimento da sociedade moderna - Volume I 1818-1841. São Paulo: Boitempo.

Jones, Gareth Stedman (2017) Karl Marx: grandeza e ilusão. São Paulo: Cia. das Letras.

Marx, Karl ((2010) [1844]) Sobre a questão judaica. São Paulo: Boitempo.

Marx, Karl ((2005) [1843]) Crítica da Filosofia do Direito de Hegel. São Paulo: Boitempo.

Mehring, Franz ((2013) [1918]) Karl Marx: a história de sua vida. São Paulo: José Luis e Rosa/Sundermann.

Muller, Jerry Z. (2011) Os Judeus e o Capitalismo Mundial: o que explica o sucesso judaico nas sociedades capitalistas? São Paulo: Saraiva.

Pilgrim, Volker Elis (1992) Adieu Marx: violência e exploração no ambiente familiar. Rio de Janeiro: Imago.

Sperber, Jonathan (2014) Karl Marx: uma vida do século XIX. São Paulo: Amarilys.

Wheen, Francis (2001) Karl Marx. Rio de Janeiro: Record.

${ }^{93}$ Marx's atheism must be studied from the point of view of the consequences of abandoning the religious tradition of his family. As Carvalho (2015, p. 175) observes: "Atheism is not a homogeneous phenomenon: there is one for each religion [...] it is not the same to abandon Christianity or Buddhism, Islam or Judaism. The atheist of Jewish origin, for example, rarely fails to adhere, compensatory, to some political utopianism, where he finds an Ersatz of the prophetic outcry of justice. He did not, after all, abandon the 'Father', but the 'Law'". 